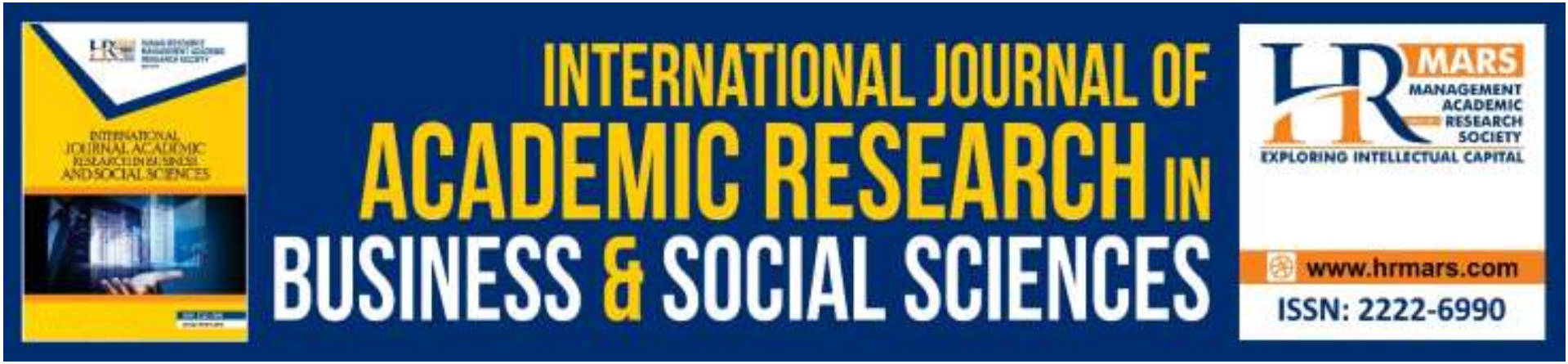

\title{
Content Knowledge Competency of Arabic Language Teacher Trainees during Teaching Practice
}

\section{Zarima Mohd Zakaria, Azizah Atan, Robe'ah Yusuf, Suo Yan Mei}

To Link this Article: http://dx.doi.org/10.6007/IJARBSS/v9-i9/6295

DOI: 10.6007/IJARBSS/v9-i9/6295

Received: 12 July 2019, Revised: 01 August 2019, Accepted: 29 August 2019

Published Online: 11 September 2019

In-Text Citation: (Zakaria, Atan, Yusuf, \& Mei, 2019)

To Cite this Article: Zakaria, Z. M., Atan, A., Yusuf, R., \& Mei, S. Y. (2019). Content Knowledge Competency of Arabic Language Teacher Trainees during Teaching Practice. International Journal of Academic Research in Business and Social Sciences, 9(9), 307-319.

Copyright: () 2019 The Author(s)

Published by Human Resource Management Academic Research Society (www.hrmars.com)

This article is published under the Creative Commons Attribution (CC BY 4.0) license. Anyone may reproduce, distribute, translate and create derivative works of this article (for both commercial and non-commercial purposes), subject to full attribution to the original publication and authors. The full terms of this license may be seen at: http://creativecommons.org/licences/by/4.0/legalcode

Vol. 9, No. 9, 2019, Pg. 307 - 319

Full Terms \& Conditions of access and use can be found at http://hrmars.com/index.php/pages/detail/publication-ethics 


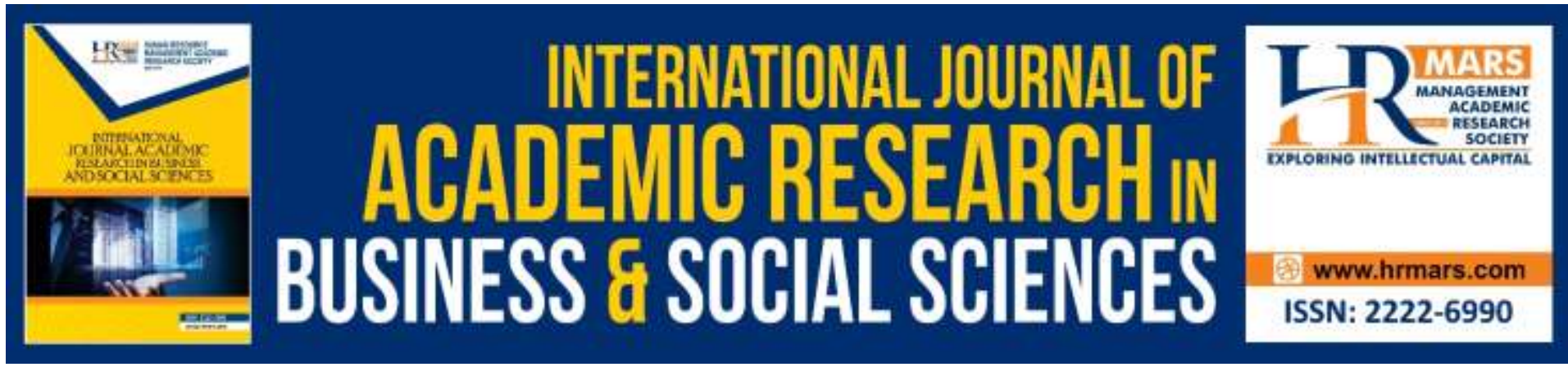

\title{
Content Knowledge Competency of Arabic Language Teacher Trainees during Teaching Practice
}

\author{
Zarima Mohd Zakaria, Azizah Atan, Robe'ah Yusuf, Suo Yan \\ Mei \\ Faculty Languages and Communication, Sultan Idris Education University, Perak \\ Malaysia
}

\begin{abstract}
This paper investigates the content knowledge competencies of 58 Arabic trainee teachers during their 14-week teaching practice. The competency aspect focused is the level of content knowledge in three areas of Arabic language-specific knowledge including grammatical knowledge/syntax, Arabic morphology, Balaghah and Adab Nusus. This study is a quantitative study which employs the descriptive research approach. Data collection was based on questionnaires which were then analyzed using SPSS statistical analysis. The findings showed that the Arabic language trainee teachers' competency level in the field of Arabic morphology was good, but the knowledge of grammar and Balaghah/Adab Nusus was only at moderate level.
\end{abstract}

Keywords: Teaching Competency, Content Knowledge, Arabic Teacher Trainees, Teaching Practice

\section{Introduction}

Teaching a foreign language such as the Arabic language is of main concern among teacher educators whereby teacher trainees need to able to ensure that they can create activities that can make the classroom teaching process as effective as possible. Language teaching is a complicated task which requires sufficient resources and skillful teaching; which in turn, necessitates considering all cognitive, affective, and social variables. As such, one of the most crucial issues pertaining to effective classroom teaching is teacher competence (Shahmohammadi, 2015). Competence refers to the knowledge, skills and personal characteristics or personality traits required in performing a task or responsibility. It means qualifications, abilities, willingness and capability to carry out a task. According to Syah (2000), teacher competence is the ability of a teacher to perform his responsibilities and duties. Competent and professional teachers are teachers who meet special eligibility standards in the implementation of their profession. Haron (2006) in Syed Jaafar (2004) presents teachers' competencies to be seen through three key aspects: cognitive competence, effective competence and behavioral competence. According to Ibrahim and 
Sani (2012) cognitive competence is the element of teacher knowledge, which is the ability of teachers to continuously improve their knowledge to improve their self-efficacy.

Effective teaching competence is the ability of teachers to utilize and apply the knowledge and the skills acquired to perform their tasks well to achieve the educational objectives. While behavioral competence is personal values and behaviors that are appreciated and practiced by teachers. Based on the competency components mentioned above, this study investigates content knowledge components of the Arabic language trainee teachers of UPSI as the objective of this study. As a trainee teacher, mastering the content of knowledge is important to ensure the teaching and facilitating process is realized. Content knowledge involves the knowledge of a teacher in translating the knowledge in the classroom as well as skills in teaching special topics (Zarima, Robe'ah, Suo, \& Wan Mazlini, 2017; Zaidah, 2005). It is also a construct that is used to explain the field of understanding of a teacher towards the subject taught before being translated into the teaching in the classroom. This is because a teacher needs to be able to relate the pedagogical skills he possesses with the knowledge of the subject content to his students. Pedagogical content knowledge is of importance as it identifies the distinctive bodies of knowledge for teaching. It represents the blending of content and pedagogy into an understanding of how particular topics, problems, or issues are organized, represented and adapted to the diverse interests and abilities of learners, and presented for instruction (Shulman, 1987).

\section{Literature Review}

\section{A. Content Knowledge}

The mastery of content knowledge is the mastery of subject matter by teachers in their respective fields (Novice \& Schools, 2014). With this knowledge acquired, teachers can perform their duties and responsibilities more effectively in the delivery of teaching, classroom management and understanding of their students. The ability of teachers to teach effectively is an important aspect of any education system. The development of teacher knowledge and pedagogical skills is a priority. In-depth knowledge of language needs to be balanced with the skills of using it. For example, Arabic teachers should master all components of Arabic-related language usage; phonology, syntax, morphology, balaghah, semantics, Arabic cultural history, and other language related content knowledge to be able to apply that knowledge in everyday learning, and be able to create relevant connections between content taught and the respective subjects (Sardjono, 2012).

According to the Teacher's Competency Standard in British Columbia, Canada (2018), professional educators need to have extensive and deep knowledge of the subjects taught. The teacher is considered competent in the field of curriculum when he communicates eloquently in English or French. In addition, they also need to understand the basic concepts and structure of the subjects taught and also understand how knowledge about subjects is built, structured and related to other fields. Beare (2001) identified five main components that are considered necessary to be competent. One of the main components is knowledge of the curriculum. The curriculum component demands teachers to master the knowledge of the content of the taught courses (subject specialty) and this must be constantly updated. Under the Teacher Educators Standard of the Netherlands (2012), content competence is categorized under the General Competency Group. Through content competency of the curriculum, teachers can gain and retain their knowledge and skills in their respective fields 
such as the content of subjects taught, pedagogical content knowledge and educational theory. In addition, teachers can integrate complex teaching practices that include content, pedagogy, educational theories, learning and psychological developments to a well-organized (Noor Shamsinar et al., 2017).

\section{Problems in Acquiring Content Knowledge}

Within the context of Arabic language teaching in Malaysia, emphasis on communication and application aspects is a priority (Zaini et al., 2017). According to Pilus (2002) (in Azman and Goh, 2010) language teachers still lack sufficient knowledge and skills in carrying out their responsibilities as an educator. As Kamarul Shukri and Mohd Hazli Yah (2008) stated that the exact language skills requirements Arabic language teachers in Malaysia have not been accurately identified. In fact, there is no instrument for the purpose of measuring the level of competence of teachers in Arabic language teaching. However, some studies have concluded that the limited and shallow understanding of the Arabic language is stated to be the cause of limited content knowledge. It was also concluded that the time allocation for the subject was not a contributing factor.

This is in line with the study conducted by Zaini et al. (2017) on the problems in the teaching of Arabic language in Malaysia that raised questions about teacher qualifications. One issue is that teachers who are not Arabic language optioned or new teachers who lack experience contribute to the problems of Arabic language teaching in Malaysia. In addition, studies show that not all Arab language teachers have an Arab language background. This is which states that non-option teachers are not capable and do not have the specific content knowledge on appropriate teaching methods and have limited language skills. However, experienced teachers are also reported to be problematic because of lack of training in the teaching of this subject (M Amarudin, 2016).

Mohamed, Muhammad, \& Jasmi (2012) discovered that there are various problems which arisen from the lack of grammar knowledge of the Arabic language teacher's themselves. The number of teachers who major in Arabic grammar is also very limited. Arabic grammar is a very difficult language learning component because it contains complex concepts and terms (Ideris, 2012). In Arabic grammar teaching, attention should be given to the language itself which has its branches in various fields such as reading and understanding (muthala'ah), the creation of sentences and essays (insya '), texts and memorization (mahfuzat), writing (imla 'and khat), grammar (qawa'id), literature (adab), and rhetoric (knowledge balaghah). All of the fields mentioned are considered as the main learning components in Arabic language grammar. It is one of the branches of knowledge that focuses on the functional aspects of a word in determining the position of a word and whether it can be categorized as the word I'rab or binaa'. This field will ensure that reading texts and writing conform to proper and correct Arabic grammar rules. While rhetorical knowledge (balaghah) is a method that allows speakers to speak fluently and to understand rhetorical texts in Arabic.

There were a few issues related to the Sultan Idris Education University Arabic language teacher trainee's competencies put forward by practicum supervisors (lecturers) and mentor teachers counseling teachers. Among these, a majority of the supervisors identified some errors in the use of dhomirs and dhomir jama 'lilmuzakkar and dhomir jama' lil muannath in trainees' verbal instructions as well as in writing their lesson plans. Likewise there still exist misuse of fi'il amar. In addition, there are often mistakes in the use of Alif Lam Ma'arifah in the formation of the phrase Mudhaf and Mudhafan Ilaih. While the trainee 
teachers' weakness in mastering rhetorical knowledge was identified in the difficulty of understanding poetic verses with traditional words or style. Therefore, based on the problems mentioned above, this study is of interest to examine the competency aspects of Arabic language teacher trainees in mastering the content knowledge in order to produce effective teachers with proficient language skills, knowledgeable about language which includes morphology, syntax, rhetoric and pedagogical skills. This is in line with the vision and mission of the Malaysian Ministry of Education under Malaysia Education Blueprint 2013 - 2025 (2013) which enhancing teacher coaching and support to improve delivery of knowledge, skills, and values across all academic and non- academic aspects of curriculum.

\section{Research Findings}

This study involved the use of questionnaires which is considered as a logical, scientific and specialized research tool. Data were collected from 32 schools in Perak and Selangor where 58 UPSI Arabic teacher trainers were undergoing their teaching practice. The questionnaire was constructed based on the objectives of the study which is to investigate the content knowledge competency of Arabic language teacher trainees in three areas of the Arabic language. Part A involves 12 items covering the competence of trainee teachers on grammatical knowledge / Arabic syntax. While in section B, there are 10 items that look into the level of knowledge of Arab morphology, and part C consist 15 items which evaluated the field of rhetoric / Arabic balaghah.

The data were analyzed using descriptive analysis presented in the form of frequency and percentage to measure the competency level of Arabic language trainers in Arabic language content knowledge. The measurement scale items in the content knowledge component is assessed on the following five Likert scale; 1 Strongly disagree (1.00 to 1.49), 2 Disagree (1.50 to 2.49), 3 Not sure (2.50 to 3.49), 4 Agree (3.50 to 4.49) and 5 Strongly agree (4.50 to 5.0). It is then analyzed and summed up to three levels of competence: 1 Low level (1.00 to 2.33), 2 Medium Level (2.34 to 3.66), 3 High Level (3.67 to 5.00). The findings of the three specific content knowledge components of Arabic language teacher trainees are described in the following three tables. 
Content Knowledge Competency of Arabic Language

Table 1: Content knowledge competency of grammar

\begin{tabular}{|c|c|c|c|c|}
\hline & Mastery of Knowledge / Syntax & Mean & SD & Level \\
\hline 1 & $\begin{array}{l}\text { I am skilled in constructing a simple } \\
\text { Arabic phrase (Tarkib Al-Jumal) }\end{array}$ & 3.91 & 0.86 & 3 \\
\hline 2 & $\begin{array}{l}\text { I emphasize the inflection aspect (Al-I'rab) } \\
\text { in understanding the meaning of the } \\
\text { word }\end{array}$ & 3.33 & 0.90 & 2 \\
\hline 3 & $\begin{array}{l}\text { I can easily determine the genus (gender) } \\
\text { whether the genus is basic or } \\
\text { grammatical }\end{array}$ & 3.74 & 0.83 & 3 \\
\hline 4 & $\begin{array}{l}\text { I understand the numbers concept / } \\
\text { Single (mufrad), Dual (Muthanna) and } \\
\text { Many (Jama ') }\end{array}$ & 3.96 & 0.95 & 3 \\
\hline 5 & $\begin{array}{l}\text { I am able to distinguish special nouns (Al- } \\
\text { Ma'rifah) and general nouns concept (Al- } \\
\text { Nakirah) }\end{array}$ & 4.14 & 0.94 & 3 \\
\hline 6 & $\begin{array}{l}\text { I master the concept of three verbs, } \\
\text { namely; the past tense verb Al-Fiil Al- } \\
\text { Madhi, the present verb (Al-Fiil Al- } \\
\text { Mudhari ') and the future tense verb (Al- } \\
\text { Fiil Al-Amar) }\end{array}$ & 4.09 & 0.86 & 3 \\
\hline 7 & $\begin{array}{l}\text { I am able to identify basic root words or } \\
\text { compound words (Masdar) }\end{array}$ & 3.64 & 0.87 & 2 \\
\hline 8 & $\begin{array}{l}\text { I understand the concept of Fa'il } \\
\text { (Performer) whether known (Ma'alum) or } \\
\text { unknown (Majhul) }\end{array}$ & 4.03 & 0.95 & 3 \\
\hline 9 & $\begin{array}{l}\text { I am knowledgeable in the Word Number } \\
\text { concept (Aadad Maadud) and how to use } \\
\text { it in a phrase }\end{array}$ & 3.67 & 0.80 & 3 \\
\hline 10 & $\begin{array}{l}\text { I am proficient in identifying Maf'ul Bih, } \\
\text { Maf'ul Fih, Maf'ul Ma'ah. }\end{array}$ & 3.67 & 0.98 & 3 \\
\hline 11 & $\begin{array}{l}\text { I am proficient in using sentence } \\
\text { connectors (Isim Mausul) in the phrases/ } \\
\text { sentences }\end{array}$ & 3.84 & 0.95 & 3 \\
\hline 12 & $\begin{array}{l}\text { I can efficiently select relevant particles } \\
\text { (Harvard Jar) in forming a phrase / verse }\end{array}$ & 4.00 & 0.84 & 3 \\
\hline \multicolumn{2}{|r|}{ Total } & 3.47 & 0.75 & 2 \\
\hline
\end{tabular}

Reference: 1= Poor (1.00-2.33), 2= Moderate (2.34-3.66), 3= Good (3.67-5.00)

Table 1 shows the findings of the study on content knowledge of the Arabic language grammar. The overall findings indicated that the grammar knowledge competency is at a moderate level with a mean value of 3.47 (standard deviation $=0.75$ ). A total of 12 items were constructed, 10 of which were good while two constructs were at basic level. The teacher 
trainees achieved the highest mean value of 4.14 for the fifth item. The item which showed the lowest score was the second item with a min score of 3.33 .

\section{Content Knowledge Competency of Arabic Morphology}

Table 2: Content knowledge competency of Arabic language morphology

\begin{tabular}{|l|l|c|c|c|}
\hline & \multicolumn{1}{|c|}{ Mastery of Morphology } & Mean & SD & Level \\
\hline 1 & $\begin{array}{l}\text { I can differentiate letters, nouns } \\
\text { and verbs in words }\end{array}$ & 4.29 & 0.77 & 3 \\
\hline 2 & $\begin{array}{l}\text { I can differentiate sohih akhir } \\
\text { muutal akhir verbs }\end{array}$ & 3.88 & 0.97 & 3 \\
\hline 3 & $\begin{array}{l}\text { I know the marfu position for Fiil } \\
\text { (verb) }\end{array}$ & 4.77 & 0.17 & 3 \\
\hline 4 & $\begin{array}{l}\text { I know the marfu position for } \\
\text { Isim (noun) }\end{array}$ & 4.03 & 0.92 & 3 \\
\hline 5 & $\begin{array}{l}\text { I know different categories of } \\
\text { Isim Fa'il and Isim Maf'uul }\end{array}$ & 3.94 & 0.74 & 3 \\
\hline 6 & $\begin{array}{l}\text { I can identify Isim Kana Khabar } \\
\text { Inna }\end{array}$ & 3.69 & 0.84 & 3 \\
\hline 7 & $\begin{array}{l}\text { I can identify Khabar Kana Isim } \\
\text { Inna }\end{array}$ & 3.71 & 0.75 & 3 \\
\hline 8 & $\begin{array}{l}\text { I have in depth knowledge of } \\
\text { Taukid and Badal concept }\end{array}$ & 3.70 & 1.03 & 3 \\
\hline 9 & $\begin{array}{l}\text { I know and understand tasrif of } \\
\text { verbs and how to use them in } \\
\text { words }\end{array}$ & 4.00 & 0.95 & 3 \\
\hline 10 & $\begin{array}{l}\text { I know and understand dhomir's } \\
\text { tasrif and its use in sentences }\end{array}$ & 3.91 & 0.86 & 3 \\
\hline & \begin{tabular}{l} 
Total \\
\hline
\end{tabular} & 4.20 & 0.62 & 3 \\
\hline
\end{tabular}

Reference: 1= Poor (1.00-2.33), 2= Moderate (2.34-3.66), 3= Good (3.67-5.00)

Table 2 shows the overall findings of the study on the knowledge pertaining to morphology. The overall findings indicated that the morphology knowledge competency is at a high level, achieving the mean value of 4.20 (standard deviation $=0.62$ ). A total of 10 items were constructed and all showed high levels of competency. The findings also showed that the third item score was the highest level of value $(\min =4.77, \mathrm{Sd}=0.17)$. Whereas, the lowest score was for item 6 with a mean value (mean $=3.69, \mathrm{Sd}=0.84$ ). 
Content Knowledge Competency of Arabic Balaghah /Adab Nusus

Table 3: Content knowledge competency of Arabic Balaghah / Adab Nusus

\begin{tabular}{|c|c|c|c|c|}
\hline & $\begin{array}{l}\text { Mastery of Balaghah / Adab } \\
\text { Nusus }\end{array}$ & Mean & SD & Level \\
\hline 1 & $\begin{array}{l}\text { I have in depth knowledge of of } \\
\text { Tasybih, Tashbih Principles and } \\
\text { examples of each }\end{array}$ & 3.76 & 0.90 & 3 \\
\hline 2 & $\begin{array}{l}\text { I have in depth knowledge of Al- } \\
\text { haqiqat Wal Majaz, its division } \\
\text { and types }\end{array}$ & 3.62 & 0.97 & 2 \\
\hline 3 & $\begin{array}{l}\text { I have in depth knowledge of Al- } \\
\text { Kinayah and the divisions of } \\
\text { Kinayah }\end{array}$ & 3.46 & 0.90 & 2 \\
\hline 4 & $\begin{array}{l}\text { I understand the topic of Maani } \\
\text { Science, the topic debate and } \\
\text { the benefits of learning it }\end{array}$ & 3.53 & 0.86 & 2 \\
\hline 5 & $\begin{array}{l}\text { I understand the topics of Qaul } \\
\text { and Kalam }\end{array}$ & 3.45 & 0.88 & 2 \\
\hline 6 & $\begin{array}{l}\text { I have in depth knowledge of } \\
\text { Ilmu Badii }\end{array}$ & 3.39 & 0.95 & 2 \\
\hline 7 & $\begin{array}{l}\text { I understand the importance of } \\
\text { Jinas }\end{array}$ & 3.59 & 0.92 & 2 \\
\hline 8 & I understand the topic Saja' & 3.57 & 0.94 & 2 \\
\hline 9 & $\begin{array}{l}\text { I understand the use of the Al- } \\
\text { Khayal concept in a text }\end{array}$ & 3.19 & 0.78 & 2 \\
\hline 10 & $\begin{array}{l}\text { I can distinguish the different } \\
\text { use of Arabic texts in modern } \\
\text { and classic prose }\end{array}$ & 2.83 & 0.96 & 2 \\
\hline 11 & $\begin{array}{l}\text { I understand the concept of Al- } \\
\text { Istia arah and its use in texts }\end{array}$ & 3.50 & 0.94 & 2 \\
\hline 12 & $\begin{array}{l}\text { I can distinguish between Al- } \\
\text { Uslub Al-Khabari and Al-Uslub } \\
\text { Al-Insyai }\end{array}$ & 3.74 & 0.95 & 3 \\
\hline 13 & $\begin{array}{l}\text { I understand the concept of Al- } \\
\text { lqtibas in Quranic verses and } \\
\text { Hadiths }\end{array}$ & 3.27 & 0.81 & 2 \\
\hline 14 & $\begin{array}{l}\text { I understand the concept of Al- } \\
\text { Thibaq and its types }\end{array}$ & 3.62 & 0.98 & 2 \\
\hline 15 & $\begin{array}{l}\text { I understand the concept of Al- } \\
\text { Muqabalah and can distinguish it } \\
\text { in Qur'anic verses and Hadiths }\end{array}$ & 3.55 & 1.01 & 2 \\
\hline \multicolumn{2}{|c|}{ Total } & 3.47 & 0.92 & 2 \\
\hline
\end{tabular}

Reference: $1=$ Poor (1.00-2.33), 2= Moderate (2.34-3.66), 3= Good (3.67-5.00) 
Table 3 shows the overall findings of the study on the knowledge pertaining to Balaghah / Adab Nusus. The overall findings indicated that the knowledge competency of Balaghah / Adab Nusus is at a moderate level, achieving the mean value of 3.47 (standard deviation $=0.92$ ). Thus, the findings showed that the competency level in mastering rhetoric or balaghah / adab Nusus is limited to the basic stage only. A summary of the findings of the entire study is set out in Table 4.

Table 4: Summary of overall study

\begin{tabular}{|c|c|c|c|}
\hline \multirow[t]{2}{*}{ No } & \multicolumn{3}{|c|}{$\begin{array}{c}\text { Content knowledge competency } \\
\text { of Arabic language }\end{array}$} \\
\hline & Statement & Mean & Level \\
\hline 1. & $\begin{array}{l}\text { Content knowledge of } \\
\text { Arabic grammar }\end{array}$ & 3.47 & Moderate \\
\hline 2. & $\begin{array}{l}\text { Content Knowledge of } \\
\text { Arabic Morphology }\end{array}$ & 4.20 & High \\
\hline 3. & $\begin{array}{l}\text { Content Knowledge of } \\
\text { Arabic Balaghah / Adab } \\
\text { Nusus }\end{array}$ & 3.47 & Moderate \\
\hline & $\begin{array}{l}\text { Total } \\
\end{array}$ & 3.71 & High \\
\hline
\end{tabular}

The content knowledge of the Arabic language teacher trainees of Sultan Idris Education University in Arabic morphology is at high level compared to other two field of content knowledge (mean score 4.20). The levels of knowledge of Arabic teacher trainers in two other specialized fields namely Arab grammar and Balaghah / Adab Nusus are at moderate levels (mean score 3.47). The mean total for the three levels of knowledge of the content is 3.71 and this shows the overall level of content knowledge competency the Arabic language teacher trainees is at a high level

\section{Conclusions}

Based on the Malaysian Teachers Standard (Standard Guru Malaysia, SGM, 12 Oktober 2018) teachers possess the content knowledge and understanding, and effective teaching and learning skills to enable them to function effectively as professional teachers (Idris \& Hamzah, 2013). Teachers are the most significant and costly resource in schools, teachers are central to school improvement efforts. Improving the efficiency and equity of schooling depends, in large measure, on ensuring that competent people want to work as teachers, that their teaching is of high quality, and that all students have access to high quality teaching. In line with the purpose of SGM, this study found that the level of competence of Arabic language teacher trainees in the field of knowledge acquisition and content of Arabic components was at a high level as a whole.

According to Ideris (2012), Arabic grammar is generally a topic in difficult language learning because it contains complex concepts and terms to understand. This issue is a common issue for Arab language teaching and learning scenarios. The skill of mastering grammar is not like other language skills such as listening, speaking, reading and writing skills that are usually shaped by spoken habits, practice drills and persistent exposure to the language use environment itself. In contrast to grammar skills, this skill is based on the mastery of language-related knowledge covering all forms of words, phrases, sentences and 
language styles. Each rule of grammar or sentence structure carries a certain meaning. Therefore, the use of Arabic grammar skills should be formalized, taught explicitly and practiced in other Arabic language skills.

The skill of using grammatical knowledge is also the basis for understanding rhetoric knowledge (balaghah). It is clear that the mastery of grammar requires the power of the mind relating to the thinking and skills of the application of knowledge that uses the sense of communication. Noorhayati et al. (2015) recommended the use of cards to teach Arabic grammatical structures. Pertaining to i'rab, there are also many suggestions that it should often be explained and used in determining techniques that can facilitate the learning of grammar. Noorhayati (2009) outlines ten principles of grammatical writing used in his book alKhulasah $\mathrm{Fi}$ al-Nahw. The description of the i'rab used in this book is quite distinctive, preceded by the general i'rab way, followed by examples on specific i'rab.

With reference to this, the teaching and facilitating of Arabic language grammar content learning itself needs to be constantly updated with new and improved approaches and strategies. Al'Azzawi (1995) has been extensively elaborating on the renewal movement of Arabic grammar teaching and how to facilitate modern-day teaching. Most lecturers in this area acknowledge their weaknesses in the mastery of Arabic grammar (Azhar, 2007). In addition, students who take high level Arabic language (BAT) subjects that contain Arabic rhetorical components at Arabic religious secondary schools (Sekolah Menengah Kebangsaan Agama SMKA) and government aided religious school (SABK) showed excellence especially in their examination results. However, on the average, undergraduates were found to be weak in mastering Arabic Balaghah knowledge especially when they take this course at the university level (Anuar, 2012).

Likewise, a similar scenario also exists whereby Arabic language teachers also lack mastery of Arabic Balaghah knowledge. According to Anuar (2012) there are some problems that exist among teachers in the teaching of balaghah. Teachers still use the lecture method of teaching rather than using specific grammar teaching methods/ strategies to interact while conveying the teaching of Arabic balaghah. Also, they did not provide sufficient practice as homework, either during classroom hours or outside of the classroom. Teachers give too much emphasis to the problem of Nahu and Qawa'id before the mastery of the language itself. Thus, it is more difficult for students to understand balaghah. Furthermore, it is found that most teachers are less likely to use the Arabic language as the medium of instruction in classroom teaching and often use native languages by translating the original texts during their explanations. They were also not exposed to enough and relevant professional development courses for the opportunity to be exposed to the latest information pertaining new techniques and teaching strategies in teaching and Arabic as a second language.

Based on the explanations provided, the research findings also show that UPSI Arabic language teacher trainees are also faced with similar problems and restrictions. Their content knowledge mastery is at the moderately high level during the teaching practice. This is a sequence of educational their educational background learning experience when they were in the university or at secondary school. Overall, this study finds the Arabic language teacher trainees' content knowledge competency is at a satisfactory high level. Their effectiveness as teachers are also dependent upon the process of teaching and learning directly related to the experience of trainees' teachers during the macro and microteaching sessions in the classroom as well as their ability to adapt themselves professionally with current school context. 
These findings also support the concept of expertise recommended by Khairul (2014) stating that cognitive and affective improvements can be obtained directly through classroom teaching experience. Ghazali, Rahimi and Shah (2010) emphasized that teacher trainers are the success factors of language learning in the classroom. The teaching force factors can be seen from three angles; language teaching skills, mastering the content knowledge and language teacher personality. Teachers' pedagogical content knowledge, professional knowledge and understanding are complemented by a repertoire of teaching strategies for different educational contexts. Teachers at all levels need to possess high language proficiency, command of subject matter knowledge and the application of pedagogical content knowledge. In conclusion, the content knowledge competency of the Arabic language teachers whether trainees, novice teachers or experienced teachers need to be upgraded from time to time in line with the 21st century Arabic language education needs.

\section{Acknowledgement}

This paper is based on the research project entitled Profesionalisme Guru-guru Pelatih Bahasa Arab dalam Latihan Mengajar di Universiti Pendidikan Sultan Idris. The authors would like to extend their gratitude to the Research Management and Innovation Centre (RMIC), Sultan Idris Education University (UPSI) for the University Research Grants (code: 2016-0025-106-1) that helped fund the research.

\section{Corresponding Author}

Zarima Mohd Zakaria (Dr.),

Arabic language Senior Lecturer,

Modern Languages Department,

Faculty of Languages and Communication, Sultan Idris Education University,

Tanjong Malim, Perak, Malaysia. zarima@fbk.upsi.edu.my.

\section{References}

Al'Azzawi, N. R. (1995). Fi harakah tajdid al-nahwu wa taysiruhu fi al-'asr al'hadith, Baghdad. Anuar S. (2012). Level of Student Success in the Study of Arabic Retoric in the State Religious Schools of SAR (Melaka). National Conference on Arabic Language Teaching and Learning 2012 (PKEBAR'12), National University of Malaysia, Bangi : 49-63.

Beare, H. (2001). Creating the Futures School. London: Rouletdge, Falmer.

Yusri, G., Rahimi, N. M., \& Shah, P. M. (2010). Sikap pelajar terhadap pembelajaran kemahiran lisan bahasa Arab di Universiti Teknologi MARA (UiTM). GEMA Online ${ }^{\circledR}$ Journal of Language Studies, 10(3): 15-33

Haron, Z. (2006). Kajian Kompetensi Pegawai Kanan Polis Diraja Malaysia Kontinjen Terengganu in Syed Jaafar Syed Ali (2014): Kompetensi Guru dalam Pengajaran Amali Teknologi Pembinaan di Kolej Vokasional. Master dissertation of technical education: Universiti Tun Hussin Onn Malaysia.

Ibrahim, S. S., \& Sani, M. (2012). Standard Kompetensi guru Malaysia. Retrieved from: http://www.fp.utm.my/ePusatSumber/listseminar/medc2012/pdf/159.pdf

Ideris, A. R. (2012). Ciri-ciri Inovasi Kad Pintar Nahu Arab. National Conference of Pengajaran Dan Pembelajaran Bahasa Arab 2012 (PKEBAR'12) , Universiti Kebangsaan Malaysia, Bangi. 82-100. 
Idris, N. H., \& Hamzah, R. (2013). Nilai profesionalisme bakal guru berteraskan indikator Standard Guru Malaysia (SGM). Sains Humanika, 60(1).

Izuddin, M. (2013). Kesediaan Mengajar Bahasa Arab dalam Kalangan Pelajar DPLI j-QAF: satu kajian kes. Jurnal IPG KBA Vol 5: 2013. Kuala Lumpur: IPG Kampus Bahasa Antarabangsa.

Jefridin, P. (2002). Penggunaan pendekatan komunikatif dalam pengajaran bahasa Arab komunikasi; satu kajian di SMAP Labu. Master Project Paper, Universiti Kebangsaan Malaysia in Azman C.M \& Goh Y. S. (2010). Foreign language learning situation at the Institute of Higher Education: a comparison between Arabic, Mandarin and, AJTLHE ASEAN Journal of Teaching and Learning in Higher Education, 2 (2). pp. 9-21. Vol. 2, Julai00202010, 9-20, Universiti Teknologi Mara: Malaysia.

Shukri, K. M., \& Yah, M. H. A. (2008). Pendidikan Bahasa Arab di Malaysia: Tinjauan Literatur Mengenai Tahap Penguasaan Bahasa. Pendidikan Bahasa, 8(2), 91-102.

Khairul, A. (2014). Tahap Kesediaan Guru Pelatih Institut Pendidikan Guru Dalam Latihan Mengajar. Master Disertation of Education in Technical and Vocational, Faculty of Education in Technical and Vocational, Tun Hussein Onn Malaysia University.

Amarudin, M. S. (2016). Kompetensi Guru Bahasa Arab Dalam Pembentukan Karakter Siswa Dalam Pembentukan Karakter Siswa Di Madrasah Aliyah Salafiyah Kajen Pati. Yogyakarta: UIN Sunan Kalijaga Yogyakarta.

Malaysian Ministry of Education. (2013). Malaysia Education Blueprint 2013-2025 (Preschool to post secondary education) . Kementerian Pendidikan Malaysia: Putrajaya.

Mohamed, A. K., Muhammad, A., \& Jasmi, K. A. (2012). Permasalahan Pengajaran Nahu Bahasa Arab Kepada Pelajar Sarjana Muda Sains Serta Pendidikan (Pengajian Islam). Retrieved from

http://eprints.utm.my/id/eprint/22607/1/AhmadK2003_PermasalahanPengajaranNa huBahasaArab.pdf

Muhammad, A. B., Abdullah, A. H. B., Suratman, A. S. B., Jasmi, K. A. B., \& Mustari, M. I. B. (2007). Tahap Profesionalisme Guru-Guru Pelatih Pendidikan Islam Dalam Latihan Praktikum. Research report Vot 75215. Pusat Pengajian Islam dan Pembangunan Sosial Universiti Teknologi Malaysia. Retrieved August $13 \quad 2017$ from http://eprints.utm.my/id/eprint/4276/1/75215.pdf.

Shamsinar, N. Z., Razif, A. Z., Zabidi, A., Rushdan, M. H., Hasmadi, H., Rofian , I., \& Redzauddin, M. G. (2017). Kompetensi guru bahasa Arab dalam pengajaran dan pembelajaran di Sekolah Rendah Kementerian Pendidikan Malaysia. E-Prosiding PASAK2- Vol:1 Subtema Pendidikan, Teknologi Maklumat, Politik dan Kepimpinan. Selangor International Islamic University College (KUIS). 1-12.

Noorhayati, H. (2009). Keberkesanan Kaedah Noor dalam pengajaran dan pembelajaran nahu Bahasa Arab. Unpublished Ph.D thesis, Fakulti Pendidikan, Universiti Malaya.

Noorhayati, H., Hassan Basri, M. D., \& Bhasah, A. B. (2015). The Effectiveness of Noor Method in Teaching and Learning the Phrase Number. IAFOR International Conference on Language Learning - Dubai 2015. Official Conference Proceedings.

Novice, P. C. K. O., \& Schools, S. S. (2014). Pengetahuan pedagogi kandungan guru Bahasa Iban yang baharu dengan yang berpengalaman di sekolah-sekolah menengah di Sarawak. Malaysian journal of Learning and Instruction, 11, 207-236.

Sardjono, M. (2012). Teacher Professional Competence Papers. Retrieved from Rangkaian Pendidikan Agama Islam: 
http://fajriamentari.blogspot.my/2012/12/makalah-kompetensiprofesionalguru.html

Shahmohammadi, N. (2015). Competent Teacher Characters from Students Point of View. Procedia - Social and Behavioral Sciences Volume 205, 9 October 2015, Pages 242-246. Open access retrieved from https://doi.org/10.1016/j.sbspro.2015.09.067

Shulman, L. S. (1987). Knowledge and Teaching: Foundations of the new reform. Harvard Educational Review 57: 1-22.

Standard Guru Malaysia (2018) retrieved from https://lamanbahasa.files.wordpress.com/2010/02/standard-guru-malaysia.pdf

Syah, M. (2000). Psikologi Pendidikan dengan Pendekatan Baru. Bandung: PT Remaja Rosdakarya.

Teacher's Competency Standard in British Columbia, Canada (12 Oktober 2018) retrieved from https://www2.gov.bc.ca/gov/content/education-training/k-12/teach/bcperformance-standards

Zaidah, Y. (2005). Pengetahuan pedagogikal kandungan (PPK) guru Matematik Tambahan berpengalaman: Satu kajian kes. Unpublished PhD Thesis Bangi: Universiti Kebangsaan Malaysia.

Zaini A. R, Ghazali M. R., Ismail M. R., Shamsinar, N. Z., Hamdan, H. \& Azizan, M. R. (2017). Permasalahan dalam pengajaran bahasa Arab di Malaysia. E-Prosiding PASAK2- Vol:1 Subtema Pendidikan, Teknologi Maklumat, Politik dan Kepimpinan. Selangor International Islamic University College (KUIS).

Zarima, M., Robe'ah, Y., Suo, F. Y., \& Mazlini, W. (2017). Professionalism of Arabic Teacher Trainees of Upsi in Writing Lesson Plan. World Applied Sciences Journal,35(6), 919923. 